\title{
ARTE CONCEPTUAL Y POSCONCEPTUAL. LA IDEA COMO ARTE: DUCHAMP, BEUYS, CAGE Y FLUXUS
}

\author{
Adolfo Vásquez Rocca ${ }^{1}$ *
}

Universidad Andrés Bello - Universidad Complutense de Madrid

$$
\text { http://dx.doi.org/10.5209/rev_NOMA.2013.v37.n1.42567 }
$$

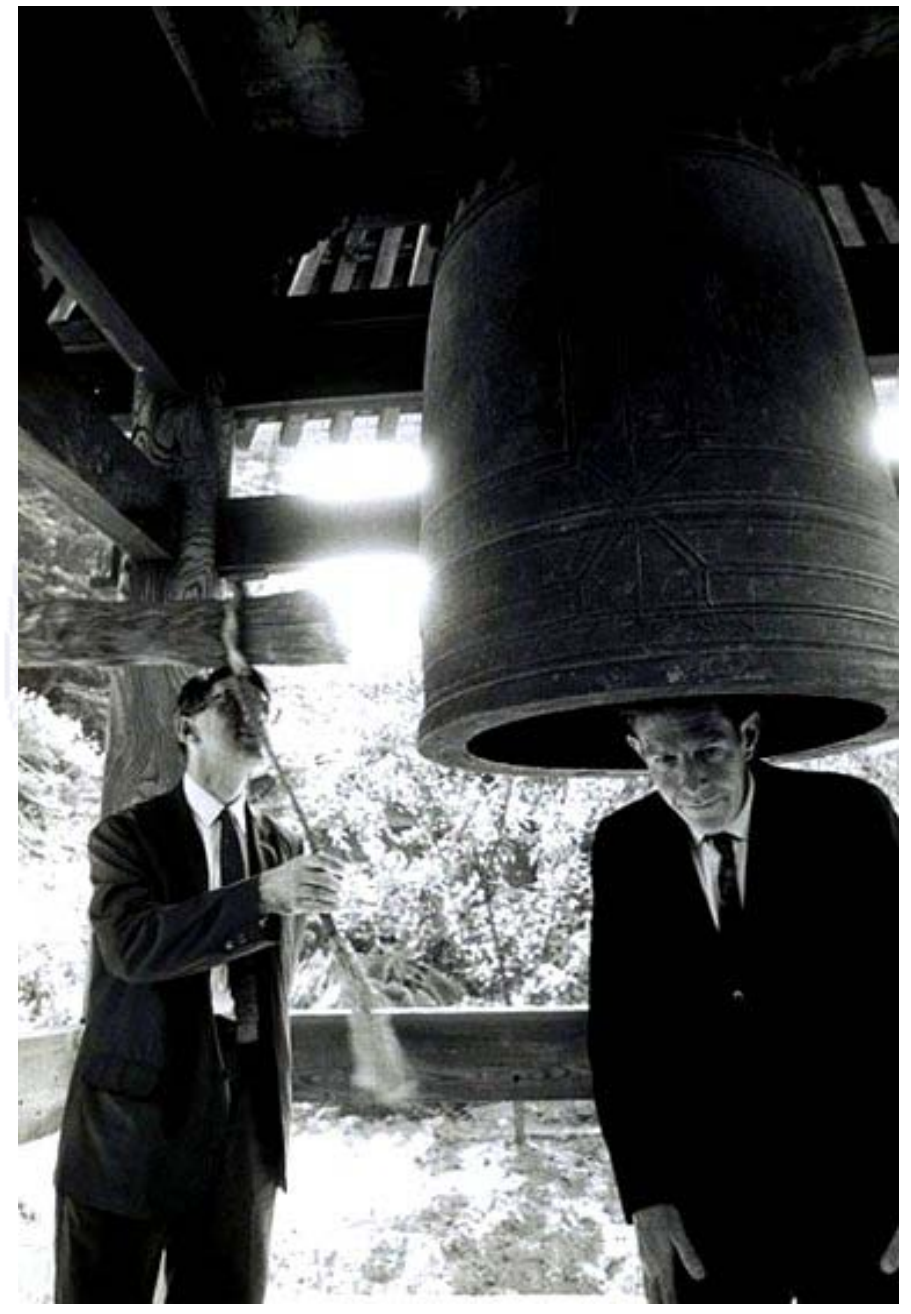

1 Doctor en Filosofía por la Pontificia Universidad Católica de Valparaíso; Postgrado Universidad Complutense de Madrid, Departamento de Filosofía IV. Profesor de Postgrado del Instituto de Filosofía de la PUCV; Profesor del Magister en Etnopsicología PUCV. Profesor Escuela de Psicología Universidad Andrés Bello UNAB. Director de Revista Observaciones Filosóficas. Profesor visitante en la Maestría en Filosofía de la Benemérita Universidad Autónoma de Puebla BUAP -Profesor visitante Florida Christian University USA y Profesor Asociado al Grupo Theoria Proyecto europeo de Investigaciones de Postgrado -UCM. Eastern Mediterranean University Academia.edu. Académico Investigador de la Vicerrectoría de Investigación y Postgrado, Universidad Andrés Bello. -Investigador Asociado de la Escuela Matríztica de Santiago. Consultor Experto del Consejo Nacional de Innovación para la Competitividad (CNIC)- Profesor Postgrado Magister en Biología-Cultural, Matríztica y Universidad Mayor, Santiago 2013. 
Resumen.- En el arte conceptual la idea o concepto prima sobre la realización material de la obra y el mismo proceso -notas, bocetos, maquetas, diálogos- al tener a menudo más importancia que el objeto terminado puede ser expuesto para mostrar el origen y desarrollo de la idea inicial. La verdadera obra de arte es la idea. El arte conceptual es un arte crítico y corrosivo, pone énfasis en lo mental, en la ideación de las obras, relegando en importancia su realización material o sensible. Junto a este reduccionismo de lo manual, existe en las obras de arte conceptual una hipervaloración del trabajo de arte, como una actividad reflexiva, tanto mental como experiencial. Los artistas conceptuales abogan por un decidido rechazo de los aspectos mercantiles del consumo de arte y al mismo tiempo, muchos de ellos intentaban imbricar su actividad artística en un contexto más amplio de preocupaciones sociales, ecológicas e intelectuales, por oposición a la producción de objetos diseñados según criterios utilitaristas y funcionales al establishment cultural. Palabras clave.- concepto, obra, arte, objeto, crítica, estética, semiótica

\section{Conceptual Art and Post-Conceptual. The Idea as Art: Duchamp, Beuys, Cage and Fluxus}

Abstract.- In conceptual art the idea or concept takes precedence over the material realization of the work and the same process-notes, sketches, models, dialogues-to be often more important than the finished object can be exposed to show the origin and development of the thought initial. The true work of art is the idea. Conceptual art is an art critic and corrosive stresses mental, in the conception of works, relegating its importance or sensitive material realization. Along with this reductionism of the manual exists in a conceptual artwork art work overvaluation as a reflective activity, both mental and experiential. Conceptual artists advocate outright rejection of consumption commercial aspects of art and at the same time, many of them trying to ingrain his artistic activity in a broader context of social concerns, environmental and intellectual, as opposed to the production of objects designed utilitarian and functional criteria to the cultural establishment.

Keywords.- concept art, artwork, object, criticism, aesthetics, semiotics

\section{1.- ARTE CONCEPTUAL Y POSTCONCEPTUAL. ${ }^{2}$}

El arte Conceptual rompe con la historiografía del arte como historia de los estilos y con la historia del arte como historia de la percepción visual y señala el fracaso de la hegemonía del arte moderno americano y sus posturas críticas reduccionistas y autoreflexivas. Se trata de visiones formalistas del arte en las que se desarrollaba la noción de "visualidad pura", que, desde la abstracción (pospictórica), derivaría hacia el Minimalismo. ${ }^{3}$

2 El presente Artículo es una edición ampliada y actualizada del Artículo "Arte Conceptual y Postconceptual" (Vásquez Rocca, Adolfo), publicado originalmente en Revista Escaner Cultural Revista de Arte contemporáneo y nuevas tendencias-, Santiago, 2006, <http://revista.escaner.cl/node/42> y preparada de forma extraordinaria para su publicación en Nomádas, UCM, 2013 (I).

3 PARCERISAS, Pilar, Conceptualismos(s) poéticos, políticos y periféricos: en torno al arte 
Desde el fin del Informalismo y los inicios del Pop; se da un progresivo fenómeno de desmaterialización del objeto artístico, en donde la obra física se convierte en mero residuo documental de la verdadera obra de arte: la experiencia misma, la idea, el concepto que subyace al objeto, en una suerte de desmaterialización del objeto artístico.

El hecho de que, en el Arte Conceptual, la visualidad ya no fuera indispensable para que una obra de arte fuera arte, puso en crisis el discurso de la crítica, hasta ese momento hegemónico, y supuso el punto de ruptura entre modernismo y posmodernismo.

En un sentido historiográfico el 'Arte conceptual' es ese movimiento que aparece a finales de los años sesenta y setenta con manifestaciones muy diversas y fronteras no del todo definidas. La idea principal que subyace en todas ellas es que la "verdadera" obra de arte no es el objeto físico producido por el artista sino que consiste en "conceptos" e "ideas". (Con un fuerte componente heredado de los "ready made" de Marcel Duchamp). "Objetos matemáticos, objetos naturales, objetos salvajes, objetos encontrados, objetos irracionales, objetos ready-made, objetos interpretados, objetos incorporados, objetos móviles." ${ }^{\prime 4}$ Todos estos tipos ofrecen el carácter común de su inutilidad práctica, de su aspecto turbador y extraño, de la arbitrariedad, contradicción y heterogeneidad de los elementos que lo constituyen.

A finales de los sesenta -con la irrupción del arte conceptual- cambiaron además las relaciones de la crítica respecto de la obra de arte. Uno de los elementos clave en este periodo fue el acercamiento de roles de críticos y artistas, muchos de los cuales empezaron a teorizar y analizar sus propios trabajos, elaborando algunos de los textos esenciales sobre Arte Conceptual. Por su lado, los críticos se adentraron con mayor profundidad en el hecho expositivo, elevando la exposición a un nivel singularmente creativo y de tesis, relegando la escritura a un segundo plano. $^{5}$

Las funciones del crítico y del artista estaban tradicionalmente divididas; al artista le concernía la producción de la obra y el trabajo del crítico era evaluarla e interpretarla. En las últimos décadas del siglo XX el desarrollo del Arte Conceptual elimina esta división. Los mismos artistas realizan también labores habitualmente reservadas a los críticos, como el comisariado (curatoría).

Los artistas conceptuales han adoptado el papel del crítico para poder definir discursivamente- las intenciones de su propio trabajo -haciendo de este aspecto

conceptual en España, 1964-1980, Editorial: Ediciones AKAL, Madrid, 2007, p. 22

4 CIRLOT, Juan Eduardo, El mundo del objeto a la luz del surrealismo, Editorial Anthropos, Barcelona, 1986, p. 82

5 PARCERISAS, Pilar, Conceptualismos(s) poéticos, políticos y periféricos: en torno al arte conceptual en España, 1964-1980, Editorial: Ediciones Akal, Madrid, 2007, p. 334 
(la referencia a sí mismo)- parte constitutiva de su arte. ${ }^{6}$ Es así como a partir del Arte Conceptual se establece la posibilidad de un diálogo entre teoría y praxis, entre saber y hacer en el ámbito de la actividad artística.

El crítico que había sido descalificado en su teorizar sobre arte porque hablaba desde fuera de la práctica misma, desde una mirada externa a la actividad artística, dando lugar a una teoría del arte inasible y que se ha volatilizado fácilmente. El artista, por su parte, inmerso en su quehacer, no poseía las herramientas discursivas para salir de su ámbito y dar cuenta de su práctica artística, así como del aparato conceptual que le subyace. Esto ha sido superado por el Arte Conceptual al establecer y clarificar los términos para el necesario debate en torno a la cuestión del estatuto ontológico del arte y deconstruir la falsa antinomia que interrogaba si el arte consistía en un saber o en un hacer, esto es, en un oficio o una técnica productiva.

La vía de acceso, el nexo que puede comunicar la factura artística y la teoría del arte está en lo que se ha denominado Arte Conceptual. En este ámbito se da cabida para que el artista teorice y para que el filósofo ejerza el oficio del artista; constituyéndose un cruce entre texto y material o entre lectura y técnica.

\section{1.- El libro de Artista: la noción del libro como idea}

De este modo la característica fundamental del Arte Conceptual radica en la abolición de la distancia entre el artista y el crítico, es decir, la tendencia de los artistas a escribir y reflexionar sobre arte, bien fuera sobre la propia experiencia, con un cuestionamiento implícito de la praxis, bien sobre el arte en general o aspectos concretos del arte de los compañeros. Una crónica personal de su proceso creativo que da lugar al Libro de Artista. El libro de artista rompe definitivamente con el concepto tradicional de libro ilustrado, basado fundamentalmente en la combinación de texto e imagen que escritores y pintores venían realizando desde la mitad del siglo XIX. Este nuevo concepto de libro, que nace por la voluntad del artista como una obra de arte, como un objeto de arte donde se dan cita el espacio y el tiempo, se arraiga definitivamente a principio de los años setenta, con la eclosión y maduración del arte conceptual. Estos libros nacieron con la intención de situar fuera del marco del espacio de la galería y de los galeristas - esto es, del comercio del arte- las informaciones sobre arte y las intenciones del artista. ${ }^{7}$ Así, el libro se convierte en un vehículo para las ideas y de aquí nace la noción del libro como idea.

Algunos trabajos de futuristas, dadaístas, constructivistas o surrealistas pueden considerarse - juntamente con la ruptura estética que operan las revistas de vanguardia -antecedentes del libro de artista de los años setenta, una herencia del propio del arte conceptual. No se puede negar que la noción de ready-made

$6 \quad$ MEYER, Ursula, Conceptual Art, Dutton, Nueva York, 1972.

7 MORGAN, Robert C.; Commentaries on the New Media Arts: Fluxus \& Conceptual Art, Artists' Books, Correspondence Art, Audio \& Video Art. 
abre primero las puertas a una mirada del libro como objeto y que su creador Marcel Duchamp, es el antecedente más lejano y, a la vez, más inmediato, del libro de artista, sobre todo con la conocida Boîte-en-Valise ${ }^{8}$, de 1936 , y que puede ser considerado el primer libro-objeto ${ }^{9}$, autónomo, o anti-libro del siglo XX. La Boîte-en-Valise inauguraba para de Duchamp otro concepto de libro de arte y así dejo constancia: "Otra nueva forma de expresión. En lugar de pintar algo, se trata de reproducir aquellos cuadros que tanto me gustan en miniatura y a un volumen muy reducido. No sabia como hacerlo. Pensé en un libro, pero no me gustaba la idea. Entonces se me ocurrió la idea de una caja en la que estarían recogidas todas mis obras como en un museo en miniatura, un museo portátil, y esto explica que lo instalara en una maleta.". ${ }^{10}$

La Boîte-en-Valise es la única de las "Boîtes" que se conceptúa como espacio y cerrado. Las otras tres (Verte, Blanche y la Boîte de 1914) tienen una naturaleza abierta y documental, y, o bien, "asisten" a una información gráfica paralela (Grand Verre, Trois Stoppages-Etalon), o simplemente esbozan ocurrencias o reflexiones aisladas.

\section{2.- Arte conceptual: semiótica, nuevos métodos de análisis y teorías sociológicas relacionadas.}

El mundo del arte parece exclusivamente preocupado con la semiótica, "la crisis de representación" y otras inquietudes académicas.

La critica como tal se vio influida por nuevos métodos de análisis relacionados, principalmente, con las teorías del lenguaje, el estructuralismo o la semiótica, y adoptó referentes como las reflexiones de Rolan Barthes en Critique et verité (1968) o La mort de l'auteaur en Essais Critiques (1964), o bien tomó como modelos los ensayos de Julia Kristeva. Tampoco puede olvidarse el influjo del marxismo, la sociología o el enfoque psicologista fruto de un conocimiento más profundo de Freud y Lacan, en el análisis de la obra de arte. Otros autores figuran entre las lecturas obligadas: Lukács, Noam Chomsky, Michel Foucault, Pierre Francastel y sus Études de sociologie del' art (1970), Arnold Hauser con Der Ursprung der modern Kunst und Literatur (1964), Theodor W. Adorno y Aesthetische Theorie ${ }^{11}$ (1970), Galvano della Volpe y Storia del gusto (1971), Heber Marcuse y One dimensional man: Studies in the Ideology of Advance Industrial Society (1964), Ernest Fischer con The necessity of Art, René Berger y

8 DUCHAMP, Marcel Boîte-en-Valise, 1936-41. Caja de cartón con réplicas en miniatura, fotografías y reproducciones en color de obras del artista, 1936.

$9 \quad$ Anteriormente, Duchamp había construido La Boîte, de 1914, La Boîte Blanche, con notas datadas entre 1914 y 1923, y la Boîte verte, de 1934. En esta caja se recogen notas, procesos de trabajo, reproducciones y otros elementos que ayudan a entender Le Gran Verre. La Mariée mise â un par ses célibataires même (1915-1923).

10 Texto de Marcel Duchamp citado en el catálogo de la antológica Duchamp, Fundación Joan Miró, Barcelona, 1983

${ }_{11}$ ADORNO, Theodor W., Ästhetische Theorie, Frankfurt del Main, Suhrkamp, 1970 
Art et Comunication (1972), Umberto Eco con La Definizione d'Arte (1968) o Gillo Dorfles con La oscilazione del gusto (1970). ${ }^{12}$

\section{2.- DEL ARTE CONCEPTUAL AL ANTIARTE: FLUXUS, PERFORMANCES MÚSICA CONCRETA Y OTRAS HISTORIAS DE PROVOCACIÓN. ${ }^{13}$}

El conceptualismo aparece asociado con la investigación discursiva que adopta al lenguaje como soporte. No todas las ideas tienen por qué materializarse [...] Por cada obra de arte que se materializa hay muchas variaciones que no se materializan. La potencialidad expresiva de las obras nunca realizadas- devela una ausencia, la precariedad del mundo.

En el arte conceptual la idea o concepto prima sobre la realización material de la obra y el mismo proceso -notas, bocetos, maquetas, diálogos- al tener a menudo más importancia que el objeto terminado puede ser expuesto para mostrar el origen y desarrollo de la idea inicial. Otro elemento a resaltar de esta tendencia es que requiere una mayor implicación del espectador no sólo en la forma de percibirlo sino con su acción y participación. En función de la insistencia en el lenguaje, el comentario social o político, el cuerpo o la naturaleza dentro de este arte encontramos líneas de trabajo muy diferentes: body art, land art, Process art, performance art, arte povera... Y entre sus más importantes representantes se encuentran artistas como: Joseph Beuys, Joseph Kosuth, Weiner, el grupo inglés Art and Language, Gilbert and George, Dennis Oppenheim, Walter de Maria, Robert Smithson, Jean Dibbets o Richard Long.

Respecto a la insistencia en el lenguaje cabe referirse al movimiento Fluxus ${ }^{14}$ para realizar algunas precisiones importantes.

Fluxus estaba dirigido a impactar en el público como una imitación de lo intrínsecamente vital. La complejidad de los conciertos Fluxus y la colaboración de artistas de la talla de Joseph Beuys, Wolf Vostell, Nam June Paik y Charlotte Moorman desembocaron en interpretaciones que transmitían una visión muy especial e inconformista de la vida.

Los conciertos Fluxus no son placeres auditivos de alta fidelidad y sintonía fina. No se produce una armonización acústica a través de unos bajos precisos, de unos tonos medios naturales y de tonos concomitantes cristalinos. Un concierto Fluxus es una experiencia auditiva en la que cualquier objeto, cualquier cosa se convierte

12 PARCERISAS, Pilar, Conceptualismos(s) poéticos, políticos y periféricos: en torno al arte conceptual en España, 1964-1980, Editorial: Ediciones Akal, Madrid, 2007, 335

13 MACIUNAS: G. en AA.W : L'Espirit de Fluxus. Catálogo de la exposición en la Fundació Antoni Tapies. Barcelona, 1994

14 VÁSQUEZ ROCCA, Adolfo, "Fluxus y Beuys: De la Acción de Arte a la Plástica Social", En Revista Homines -Arte y Cultura- MA-739-2004, 2009, Málaga, España. http://www.homines.com/arte_xx/fluxus_y_beuys/index.htm 
en un instrumento. La autenticidad inconfundible de los conciertos Fluxus y la pasión y el poder innovador de los artistas supusieron un cambio profundo en la expresión del arte. Esta evolución artística, incitada por el presente y dirigida hacia el futuro, creó la noción de que cada individuo constituye una obra de arte en sí mismo y que la vida se puede entender como una composición artística global. Los atributos singulares de los conciertos Fluxus y la libertad en los arreglos son un reconocimiento a la causalidad, en la que se desvanecen tanto la causa como el efecto y en la que el caos acuña su marca indeleble sobre la realidad.

De ese modo, Fluxus incide en la sociedad desde el punto de vista sociológico y psicológico y se convierten en un elemento de comunicación. El aura de excentricidad que envolvía a los artistas del movimiento Fluxus era expresión íntima de sus diferentes personalidades y caracteres y no respondía a una moda pasajera. Beuys, Vostell y Paik fueron forjando su mito en Renania. Un mito alentado en parte por su desarrollo del Videoarte.

Si se contempla la evolución de los mercados de arte internacionales desde los años 70 del siglo pasado hasta la actualidad, se dará uno cuenta de la influencia tan diversa del movimiento Fluxus, Happening y del Videoarte. La estructura y la expresión artísticas plasmadas en muchas obras de arte contemporáneo expuestas en galerías, rinden inintencionadamente un homenaje a aquellos pioneros del happening, del Fluxus y del videoarte que revolucionaron el arte durante los años 60.

Haro Lauhus inauguró su galería en 1961. El Museo Municipal de Wiesbaden acogió la primera manifestación oficial del movimiento Fluxus en AlemaniaFLUXUS, Festival Internacional de la Nueva Música del 1 al 23 de septiembre de 1962. En 1963 Rolf Jährling inauguró en Wuppertal la Galería Parnass. En 1966 Valdis Abolins inauguró en Aquisgrán la Galería Aachen. En 1969 Helmut Rywelski y Angar Nierhoff presentaron en su Galería Art Intermedia en Colonia la escultura de Wolf Vostell Ruhender Verkehr-Tráfico Bloqueado. En 1970 Inge Baecker inauguró su Galería Baecker en Bochum y René Block la suya en Berlín. Todos ellos han promocionado y apoyado a los artistas del movimiento happening y Fluxus, permitiéndoles plasmar esa evolución artística que conmocionó la sociedad de la década de los 60 y cuya influencia se percibe hasta la actualidad.

Fluxus, que se desarrolla en Norteamérica y Europa bajo el estímulo de John Cage, no mira a la idea de la vanguardia como renovación lingüística, sino que pretende hacer un uso distinto de los canales oficiales del arte que se separa de todo lenguaje específico; es decir, pretende la interdisciplinariedad y la adopción de medios y materiales procedentes de diferentes campos. El lenguaje no es el fin, sino el medio para una noción renovada del arte, entendido como "arte total".

Como Dadá, Fluxus escapa de toda tentativa de definición o de categorización. Según Robert Filliou, es "antes que todo un estado del espíritu, un modo de vida impregnado de una soberbia libertad de pensar, de expresar y de elegir. De cierta manera Fluxus nunca existió, no sabemos cuándo nació, luego no hay razón para 
que termine". Asimismo Filliou opone el Fluxus al arte conceptual por su referencia directa, inmediata y urgente a la realidad cotidiana, e invierte la propuesta de Duchamp, quien a partir del Ready-made, introdujo lo cotidiano en el arte. Fluxus disuelve el arte en lo cotidiano.

- La experimentación plástica llevada a cabo por Duchamp a través de sus ready made, en particular por la fabricación de sus "Tres zurcidos - patrón", un conjunto de tres hilos de menos de un metro fijados sobre bandas de tela pegadas sobre vidrio, y acompañadas de sus tres reglas para trazar. "Los 3 zurcidos - patrón" observa Duchamp ${ }^{15}$ - "son el metro disminuido". El conjunto se inscribe en el "género" de una matemática ficticia, de una física de lo imaginario, que sin embargo reclama los mismos títulos de rigor y exigencia que sirven de fundamento a la matemática occidental. Por ello, y lo mismo que el patrón de medida "universal" de metro, los Tres zurcidos patrón de Duchamp se guardan en un estuche especial, destinado a evitar su dilatación o contracción por efectos de la temperatura - o cualquier otra posible perturbación ocasionada por factores externos.

Ahora bien, lo decididamente subversivo en la actitud de Duchamp se cifra, ante todo, en el proceso mediante el cual se establecen esas unidades imaginarias de medida - "zurcidos", de un universo roto...-, dependiente enteramente del azar. En el primer conjunto de escritos en que fija los fundamentos conceptuales de sus experiencias plásticas, en la Caja de 1914, Duchamp formula el principio que inspira la génesis de los Tres zurcidos-patrón a partir de una pregunta abierta en tiempo condicional: "si un hilo recto horizontal de un metro de longitud cae desde un metro de altura sobre un plano horizontal deformándose a su aire y da una nueva figura de la unidad de longitud..." La realización de la experiencia, que para Duchamp entraña "la idea de la fabricación", da como resultado el establecimiento de esas tres unidades enteramente occidentales de medida. Se adoptan el rigor y la precisión máximas, característicos del pensamiento matemático, pero conjugados con la voluntad indeterminada del azar. Es como un juego: el máximo rigor, la "regla del juego", sobre un fundamento convencional y gratuito, y de cuya conjugación extraemos conocimiento y placer. Con este simulacro Duchamp modela una contrafigura irónica de la solemnidad y pretensión de absoluto de la ciencia occidental. Lo provocativo de este "gesto" estético tiene sus raíces en lo que supone de impugnación del supuesto valor universal y absoluto del pensamiento occidental. Como los zurcidos - patrón, nuestra ciencia es el resultado de un proceso de fabricación intelectual, y la validez de sus reglas una consecuencia de la aceptación de determinados presupuestos y convenciones, esto es, de peticiones de principio, asentimientos que hacemos sobre la base de la buena fe o simplemente, de las ganas.

La impugnación irónica de la reducción positivista del conocimiento a mera razón

15 DUCHAMP, Marcel, Duchamp du Signe. Écrits, éditès par M. Sanouillet, avec la collab. D'Elmer Peterson; Flammarion, París. Tr. Cast. de J. Elias y C. Hesse, rev. bibl. Por J.Rmanguera; Gustavo Pili, Barcelona, 1978. 
instrumental sirve ahora como trasfondo de la fundamentación del alcance intelectual del arte o de lo que he llamado razón estética.

La obra de Duchamp nos muestra, en definitiva, tanto en una vertiente plástica como conceptual, las infinitas posibilidades de "lectura de lo real". En Duchamp encontramos el centro de gravedad de una concepción de las operaciones mentales y artísticas abierta a una lectura de lo real como diverso y plural, a una consideración flexible y distendida de la normatividad del mundo.

Nos encontramos así ante una operación de desmantelamiento epistemológico. El dispositivo opera sobre el pretendido rigor y objetividad de las ciencias duras. Sin duda una audaz maniobra subversiva, tan propia de las vanguardias de los años '20, las que superan con mucho - en su carácter corrosivo - a sus pálidos remedos postmodernos.

La trans-vanguardia ya no es básicamente ruptura. Es academia y museo, se ha convertido en nuestra "tradición": en la tradición artística de la contemporaneidad. Desde los medios de comunicación de masas y las instituciones de cultura, públicas o privadas, el horizonte estético de la vanguardia se transmite ya como clasicismo de la contemporaneidad. ${ }^{16}$

\section{3- JOSEPH BEUYS: "CADA HOMBRE, UN ARTISTA" O EL CONCEPTO DE ARTE AMPLIADO}

Beuys es el heredero directo de toda la tradición del Idealismo y el arte Romántico del Centro y el Norte de Europa. En su educación serán fundamentales las lecturas de Novalis, Holderlin, Schiller, Jean Paul, Tieck, Nietzsche, Hegel, Kierkegaard y más tarde el teósofo y educador Rudolf Steiner, auténtica columna vertebral de sus teorías sociales que ya había influenciado poderosamente a otros artistas de esta tradición romántica como Kandinsky.

A lo largo de su itinerario, Joseph Beuys ${ }^{17}$ pretendió acabar con la idea del arte

16 JIMENEZ, José, La vida como azar; complejidad de lo moderno, Ed. Mondadori, Madrid, 1989, p.139.

$17 \quad$ Artista, profesor y activista político alemán. Nació en Krefeld el 12 de mayo de 1921. En 1940 fue piloto de un bombardero. En el invierno de 1943 su avión se estrelló en Crimea, donde los tártaros le salvaron la vida al envolverle el cuerpo con grasa y fieltro, materiales que aparecerán una y otra vez en su obra. Después de participar en diversas misiones de combate, fue hecho prisionero en Gran Bretaña desde 1945 hasta 1946. Posteriormente, Beuys estudió pintura y escultura en la Academia Estatal de Arte de Düsseldorf desde 1947 hasta 1952. Durante la segunda mitad de la década de 1950 trabajó como peón en una granja. En 1961, regresó a Düsseldorf para dar clases de escultura. Fue expulsado en 1972, por apoyar a los estudiantes radicales, pero fue readmitido seis años más tarde. Sus campañas a favor de la democracia directa, el medio ambiente y otras causas similares incluyeron la utilización de un local de la Documenta de Kassel en 1972 como oficina, la presentación sin éxito de su propia candidatura para el Bundestag (cámara del Parlamento) en 1976, y la campaña para plantar numerosos árboles en Düsseldorf. Su obra abarca desde performances como "Coyote: Me gusta América y a América 
como una práctica aislada para configurar un concepto "ampliado" del arte ${ }^{18}$, abriendo el horizonte de la creatividad más allá del ghetto del arte. El arte siempre se ha alejado de las necesidades del ser humano y se ha ocupado de innovaciones estilísticas y artísticamente inmanentes. De lo que se trata ahora sostenía Beuys- es de implicar al "cuerpo social" en su conjunto ${ }^{19}$, de dar paso, a través del arte y su concepción de ampliada de la estética a una teoría antropológica de la creatividad. Para ello en 1974 funda la "Universidad Libre Internacional" junto al premio Nobel de literatura Heinrich Böll. Se trata de una universidad sin sede, donde se ponen en práctica las ideas pedagógicas del artista, ocupando la creatividad un lugar privilegiado como ciencia de la libertad; cada hombre es un artista, con facultades creativas que deben ser perfeccionadas y reconocidas.

El artista que adhiere al programa de la continuidad arte-vida, opera bajo diversas estrategias para perpetrar el atentando cultural por antonomasia, poner las obras en libertad, en libre circulación, así las obras abandonan la Galería para actuar directamente en la realidad gracias a una disposición artística y política determinada. Este es el sentido de la proposición horizontal de Joseph Beuys "cada hombre es un artista" ${ }^{20}$, que opera la apertura de la experiencia estética creadora en el espacio público horizontal, legitimando las capacidades de mucha gente que -teniendo voluntad expresiva y sensibilidad artística- no se veían a sí mismos como artistas. El arte adquiere así un alcance social y una dimensión político-espiritual que intenta dar cuenta tanto de la precariedad como de la grandeza de lo humano como fenómeno de prodigalidad extrema, íntimamente socializadora. De allí que Beuys haya desplegado sus acciones de arte instalaciones y proyectos comunitarios- en zonas desvaforecidas 0 "de incertidumbre e inestabilidad" social, intentado introducir en la escena del arte aquello con lo que el hombre ha convivido en su historia natural como especie.

Este proceso encuentra su punto de mayor alcance en la formulación del concepto ampliado de arte y en la búsqueda de la consecución de la obra de arte total. "Esta formula -y esta búsqueda- la practicó Joseph Beuys cuando quiso articular vitalmente lo ético, lo político y lo artístico, la intentó -también- Marcel Duchamp cuando afirmó su idea de arte como filosofía crítica y la explotó Andy Warhol gracias a su prodigiosa habilidad para disolver todo gesto artístico en la esfera de las comunicaciones y el mercado o, en otra palabras, volver la mercancía obra de

\footnotetext{
le gusto yo" (1974), en la que convivió con un coyote (y un cobertor de fieltro) en una galería de Nueva York, hasta esculturas como El final del siglo XX (1983), que consiste en 21 piezas de basalto taponadas con grasa y objetos más convencionales, entre los que se incluían numerosos dibujos y acuarelas. Murió en Düsseldorf el 23 de enero de 1986.

18 "Arte ampliado": La auténtica obra de arte reside en la transformación de la conciencia del espectador para activar la realidad y el pensamiento.

19 BEUYS, Joseph, BODENMANN-RITTER Clara, Joseph Beuys: cada hombre, un artista: conversaciones en Documenta 5-1972, Editorial Visor, Madrid, 1995.

20 BEUYS, Joseph, BODENMANN-RITTER Clara, Joseph Beuys: cada hombre, un artista: conversaciones en Documenta 5-1972, Editorial Visor, Madrid, 1995.
} 
$\operatorname{arte}^{21}$

En las propuestas de Beuys se alienta el espíritu vanguardista que intenta identificar arte y vida, y proclamar que todo ser humano es depositario de una fuerza creativa. Para Beuys, esa fuerza creativa universal se revela en el trabajo. Y, por tanto, la tarea del artista no es, en su raíz, distinta de la de los no artistas.

La consecuencia más importante de estas concepciones en el desplazamiento del centro de interés creativo. Beuys no buscaba producir objetos, "obras", sino acciones. Beuys ambiciona la condición del nómada. En el reino del hombre urbano sedentario, quiere ser desplazamiento continuo. Lo nómada es la existencia en un lugar que es camino hacia todos los lugares. Es goce del movimiento; es proyección hacia el volumen completo del espacio ${ }^{22}$.

Los objetos de Beuys no son "autónomos": forman parte de un circuito comunicativo que se despliega en las acciones en que son utilizados. Y después se convierten en signos, o "documentos" según la expresión del propio Beuys, depositarios de la memoria de dichas acciones.

Para Beuys "todo conocimiento humano procede del arte" ${ }^{23}$, toda capacidad procede de la capacidad artística del ser humano, es decir, de ser activo creativamente. "El concepto de ciencia es sólo una ramificación de lo creativo en general" ${ }^{24}$. Por esa razón -sostiene Beuys- hay que fomentar una educación artística para el ser humano, pero no como una materia relegada al mero ámbito de las manualidades, sino emplazada estratégicamente en el centro del currículum académico, como el medio más eficaz en la reproducción de la inteligencia técnica y el desarrollo de nuevas miradas sobre las cosas, un campo para el ejercicio crítico de la configuración espacial. De acuerdo a estas convicciones sólo se puede preparar adecuadamente a los futuros ciudadanos mediante este tipo de entrenamiento -inspirado por un concepto de estética ampliado- en competencias necesarias para la solución de las tareas políticas del futuro -urbanísticas, energéticas y sociales-, imbricando en su quehacer todos los medios de expresión humanos.

Que las personas aprendan a mirar es importante en un sentido eminente -señala Beuys-, por ejemplo que vieran que existen conceptos de ciencia distintos, es decir que la ciencia se puede pensar desde diversos paradigmas. "La ciencia no es una cosa fija; lo que sucede es que hay fuerzas poderosas en el mundo que quieren fijar el concepto de ciencia y dejarlo encofrado". Pero qué es la ciencia en cada momento es algo que hay que estudiar con detalle. "La ciencia de los

21 VALENCIA CARDONA, Mario A., "Los orígenes del arte crítico: La metáfora Rothko", En Revista de Ciencias Humanas, UTP, 2005.

22 IERARDO, Esteban "La liebre y el coyote; encuentros con lo animal y lo secreto en la obra de Joseph Beuys", en Temakel, 2005.

23 BEUYS, Joseph, BODENMANN-RITTER Clara, Joseph Beuys: cada hombre, un artista: conversaciones en Documenta 5-1972, Editorial Visor, Madrid, 1995, p. 71

24 Ibid. 
egipcios era distinta a la de los romanos, y la de la edad moderna es diferente de la ciencia del futuro, eso está muy claro -agrega Beuys-. Así que no cabe decir simplemente que hemos llegado al fin de la historia. Hay que preguntar si el pretendido- pensamiento exacto de las ciencias naturales es la forma final del concepto de ciencia, o sólo una forma de transición". Una forma que puede dar paso según las circunstancias al futuro próximo. Así -Beuys- ve los pensamientos humanos también como plástica, la primera plástica que surgió del ser humano. Que el ser humano pueda contemplar sus pensamientos como un artista su obra, esto es, que mire en su pensamiento, esa es la propuesta de Beuys que aquí se suscribe.

\section{1.- Beuys; Arte y antropología o la violencia original de la modernidad}

Las polaridades -Arte y vida, arte y ciencia, cultura y naturaleza- aparecen en la filosofía que Beuys procesa para su propio pensamiento. Beuys buscaba esa obra de arte total, esa imagen de creador absoluto tan cara a los Románticos. Sin duda alguna, su obra se acerca más que ninguna otra a este concepto, en especial por ese dominio del lenguaje que lleva a emplear palabra e imagen. Beuys formuló con el término "proceso paralelo" la importancia del lenguaje en su obra: el elemento material del arte tiene que ir acompañado de la expresión verbal de lo espiritual.

La acción, tal y como el artista la concibe, no es un mero recreo o un acto de provocación y participación, como el "happening" de Fluxus. Es una experiencia catártica, un rito de iniciación donde -desde una perspectiva antropológica- arte y ritual van unidos de un modo dramático en operaciones chamánicas de intensa concentración y hondo alcance espiritual. Para Beuys, como se ve, el concepto del acto artístico tiene un carácter eminentemente antropológico.

Arte y vida, arte y ciencia, cultura y naturaleza... Las polaridades aparecen siempre en la obra del artista alemán y recogidas en la filosofía que procesa para su propio pensamiento. Beuys buscaba esa obra de arte total, esa imagen de creador absoluto tan cara a los Románticos. Sin duda alguna, su obra se acerca más que ninguna otra a este concepto, en especial por ese dominio del lenguaje que lleva a emplear palabra e imagen. Como vemos para Beuys el concepto del acto artístico tiene un carácter antropológico.

En Beuys son recurrentes estas puestas en escena de acciones antropológicosociales, para ello recorre el imaginario del héroe y del anacoreta: el ser que se aleja de la ciudad y luego regresa a ella, el ser que se abstrae de la sociedad y que luego vuelve a formar parte de ella, un ser que necesita "hospitalización" (por eso, el artista es trasladado en ambulancia a la habitación, y desde ella al aeropuerto). La cultura, la civilización técnica, producen inválidos. Así, Beuys se envuelve en fieltro, como un muerto viviente. El enfrentamiento entre el artista y el coyote, su recíproco amansamiento, simbolizan la reconciliación entre cultura y naturaleza. "Esta acción ejemplar, significa magníficamente el nuevo papel que Beuys confiere al artista, intérprete de la crisis, formulador de otras 
temporalidades, escucha de civilizaciones, magnetizador de los elementos, agitador de los tiempos primordiales que, por su retraimiento e inaccesibilidad, se ha de investir con el don y el poder de reactivar la cohesión colectiva y la creatividad de todos por un retorno imaginario a los tiempos primordiales, al pensamiento original de los ideales y las funciones prístinas" ${ }^{25}$.

Beuys en su indagación de lo primordial -de la naturaleza previa a toda civilización- se interna en el territorio de la animalidad y en una de sus performances experimenta "los secretos del coyote". Los aullidos del animal representan para Beuys la violenta colisión de culturas, el punto neurálgico psicológico del sistema de las energías americanas: el trauma del conflicto americano con el indio". Convivir con el animal aquí no es salida de la civilización hacia un manantial de vida universal; aquí, lo animal le otorga al artista y, por extensión al hombre, un raro poder: el de atravesar mediante una acción simbólica el vacío íntimo de una cultura para llegar hasta su fondo de angustia y opresión. La teoría crítica atraviesa la sociedad capitalista mediante el concepto y una mirada distante. Pero el artista traspasa desde dentro la desolación que el teórico crítico observa siempre desde una prudente distancia ${ }^{26}$.

Durante tres días, Beuys hurga, ausculta, camina sobre la culpabilidad reprimida de la civilización norteamericana. Culpabilidad surgida de la matanza injustificable del indio. El indio debía ser exterminado no tanto para arrebatarle sus tierras, sino por su experiencia más amplia de la libertad. El indio vivía tan libre como el coyote o el búfalo. Por eso, oprimir o exterminar al indígena fue un despedazar la propia bandera de la libertad que la sociedad norteamericana decía representar. La angustia de esta contradicción se retuerce en el fondo oscuro del alma colectiva del país del Norte.

Mediante el coyote-guía, el artista atraviesa un presente de máscaras y arriba al trauma que nació del exterminio de la libertad india. La convivencia con el animal de los aullidos es así escena simbólica para atravesar la intimidad de una cultura y regresar a su trasfondo de trauma y contradicción.

Beuys formuló con el término "proceso paralelo" la importancia del lenguaje en su obra: el elemento material del arte tiene que ir acompañado de la expresión verbal de lo espiritual. Lo ideal y lo real tienden a una convergencia dentro de la plástica social.

Como ya he indicado, una de las grandes metas de Beuys es unir arte y vida. Sólo en este sentido es posible hablar de un Beuys propiamente político empeñado en encarnar el ideario de y el concepto de escultura social, que apunta a toda manifestación que ayude al mundo a recuperar su espíritu y su solidaridad como gran motor de cambio y desarrollo de las condiciones de vida humana.

25 LAMARHE-VADEL, BERNARD, Joseph Beuys. Ed. Siruela. Madrid, 1994.

26 IERARDO, Esteban "La liebre y el coyote; encuentros con lo animal y lo secreto en la obra de Joseph Beuys", en Temakel, 2005. 


\section{4.- EL ARTE SE REPLIEGA EN SÍ MISMO}

En estas transformaciones del estatuto de lo artístico también ha entrado en crisis la noción misma de autor y el arte se ha vuelto difuso como oficio o actividad específica ejercida sólo por artistas y virtuosos. Desvaneciéndose las utopías de trascendencia mediante el arte y desarticulando desde dentro del sistema de las artes el proyecto mismo de monumentalidad sistemática en la obra de arte. El hecho es más bien indicativo de una estetización a gran escala de la realidad, osi se quiere- de una "cultura estetizada" donde la realidad según Richard Rorty ${ }^{27}$ deviene una narrativa exitosa, una pluralidad de contextos y retóricas de sentidos diversos y lenguajes que construyen verdades -afirman visiones del mundodesde la propia pulsión creadora artística, adquiriendo así, por lo demás, lo artístico un estatuto ontológico propio, no quedando ya subordinado a ser una mera representación de una realidad, sino más bien convirtiéndose en una interpelación de ella e incluso en una instalación de la misma con nuevas categorías que surgen de estas derivas con base en la pluralidad y en la fragmentación de lo real. Así pues, no se trata -simplemente- de una estetización de lo banal amparada por un proceso de masificación del gusto y del juicio estéticos; ni tampoco de la perdida de sentido histórico hasta convertir las obras en adornos y ornamentos superficiales, averiados en su sentido; tal vez uno de los recaudos que sí convendría tomar es ante el proceso de globalización del consumo de arte, donde el gusto se da como "elitismo de masas", las que consumen información artística pero con una actitud de shopping propia de la sociedad del espectáculo y el imperio de la moda, devorando las producciones artísticas, sobre todo las audiovisuales que exigen un menor esfuerzo. Prolifera así una estética que reivindica el "mundo del arte", es decir, "todo lo que tiene que ver con el arte exceptuando el arte mismo" ${ }^{28}$ : la empresa cultural que gira en torno al artista, desde los críticos conciliadores, los curadores convertidos en súperestrellas, pasando por los compradores hasta los snobistas, la farándula y los pseudo-intelectuales ${ }^{29}$.

Ante la ambigüedad, inmediatez y sensualidad de la producción artística el curador -el administrador de la "conciencia del arte"- ejerce la función de hermeneuta y editor de la obra expuesta, produciendo el texto para un catálogo, una cartografía de la exposición, un texto para la prensa, un acta para un jurado, uno para la institución, otro para la pedagogía y la sociología del gusto, finalmente un texto para para autentificar una obra; en suma, una estrategia de mercadeo a través de una amplia gama de producciones textuales -en un comercio de frases-- cuyo

27 VÁSQUEZ ROCCA, Adolfo, "Rorty: el Giro narrativo de la Ética o la Filosofía como género literario", en PHILOSOPHICA, No 29, 2006, Revista del Instituto de Filosofía de la Pontificia Universidad Católica de $\quad$ Valparaíso, $\quad$ pp. $323 \quad$ - 334 http://serbal.pntic.mec.es/ cmunoz11/vasquez42.pdf

28 GARDNER, James, ¿Cultura o Basura?, Acento Editorial, Madrid, 1996, p. .24

29 FAJARDO, Carlos. "Arte de mediocre convivencia", En: Magazín, El Espectador, Santafé de Bogotá, abril de 1999. 
objetivo tácito es el de publicitar: hacer publico y formar un público para lo obra.

Como lo señala Sloterdijk en "El arte se repliega en sí mismo": "Los museos, bienales y galerías son las instituciones actuales para la producción de visibilidad estética, y la misma producción estética se haya irremisiblemente colonizada museística y galerísticamente. Allí donde hay una galería, hacia ella fluye el arte $" 30$.

De este modo la producción del arte gira en torno a la producción de exposiciones. El aparato moderno de mediación del arte se ha instalado como una máquina de mostrar que desde hace ya largo tiempo es más poderosa que cualquier obra individual a exponer. De allí también el protagonismo que han adquirido los curadores -dado que se les consigna el rol de editar, esto es, de dar un sentido a un conjunto de producciones que si no fuera por la unidad dada por el crítico como interprete super-dotado las obras aparecerían en su radical autonomía, dispersas, sin animo de suscribir ninguna teoría del arte, ni adscribirse a tendencia alguna que le reste peso de realidad a su radical voluntad expresiva -necesariamente individual- insurrecta y resistente a ser subsumida en un catalogo homogeneizador. La producción de exposiciones, con su correspondiente tranza bursátil, su núcleo mercantil y la puesta en escena fashion como parte de las estrategias socializadoras con que el mercado del arte y la sociedad de espectáculo coquetea con una clase intelectual cada vez más farandulera, seducida por los flash y la ocasión socialite ampliada en las páginas de la prensa cultural. Esta corte con sus flancos publicitarios, sus sistemas de influencia y especulación se ha vuelto autónoma por encima del valor de las obras expuestas y no muestra en última instancia ningún otro poder creativo que el suyo propio, el de la exposición misma. Como certeramente apunta Sloterdijk en la presentación de una exposición en Alemania "El arte se repliega en sí mismo"31: El negocio del arte tiene como conflicto su hacerse visible. El negocio del arte es así un sistema de celos y exhibicionismo. En él, el deseo de las obras consiste en convertirse en objetos de deseo. El mercado los hace sensuales, el hambre de deseo los hace bellos, la obligación de llamar la atención genera lo interesante ${ }^{32}$.

Pero en su fuero íntimo las obras desean sustraerse al régimen de visibilidad, es decir, replegarse sobre sí misma. Casi nada en ella ofrece superficies vulnerables a la mirada. La obra permanece plegada, enrollada en sí misma, encuadernada en sí misma, por así decirlo, cerrada. Su día de exposición y despliegue no es hoy, tal vez ya no lo sea, tal vez no lo sea aún. No obstante tiene una forma de existencia,

30 SLOTERDIJK, Peter, "El arte se repliega en sí mismo", Documenta XI. Kassel, En Revista Observaciones $\quad$ Filosóficas, $\quad$ Sección 2007. http://www.observacionesfilosoficas.net/elarteserepliega.html

31 SLOTERDIJK, Peter, "El arte se repliega en sí mismo", Documenta XI. Kassel, En Revista Observaciones $\quad$ Filosóficas, $\quad$ Sección 2007. http://www.observacionesfilosoficas.net/elarteserepliega.html

32 VÁSQUEZ ROCCA, Adolfo, "El Arte abandona la galeríía ! ¿A dónde va.", En RÉPLICA 21

(c) , Revista Internacional de Artes Visuales, México, Abril 2008. http://www.replica21.com/archivo/articulos/u_v/542_vazquez_abandono.html 
aunque no una del tipo habitual. La presencia de la obra no es ni la presencia de su valor ni de aquello que contiene de visible. No se revela en su plenitud, se mantiene en un ángulo agudo respecto al mundo, la curiosidad no puede leerla hasta el final y consumirla, la mirada choca con las cubiertas. En algunos casos el pliegue es tan denso que uno ni siquiera puede convencerse de si en realidad hay obras en el interior. Uno vacila involuntariamente entre dos hipótesis: dentro hay algo, dentro no hay nada"33. Algo que nos recuerda que las inversiones de los artistas en sus cuadros son altas. En los objetos están sedimentados vida, ideas, tensiones. ¿Dónde está la pared blanca en la que pueda ser extendida la totalidad de superficies plegadas? ¿No sería bueno que existiera una pared así? ¿O esas obras han rehusado por su cuenta dicha pared? ¿Se han resignado ante su imposibilidad de ser descubiertas? ¿Están enfadas con la pared blanca? En aquella otra pared hay un cuadro blanco sobre fondo blanco o sólo un espacio, el vacío de un cuadro robado por su propio pintor?.

Las obras no dejan percibir nada sobre sus experiencias con paredes y galerías. Su historia previa cuenta poco en el momento. Su estar por ahí tiene algo de repentino y casual. Ahora permanecen plegadas en sí mismas ante nosotros, no alegan nada en su defensa, no muestran enojo, no toman ninguna iniciativa contra sí mismas, se preservan. Reclaman algo de espacio al margen, sin jactarse de su existencia. Están en el margen, humildes como estanterías en una bodega; puestas, no expuestas; colocadas unas junto a otras, no presentadas en primer plano $^{34}$.

¿Están tristes esas obras? ¿Tienen nostalgia de las grandes paredes vacías? ¿Se sienten no realizadas en su íntimo ser-para-la-compra? ¿Simulan ante las grandes exposiciones una capacidad para el exilio de la que se arrepienten secretamente?

¿Pueden los artistas ensimismarse y convertirse en autistas, abandonar el arte sin exponer? Pero qué es lo que tendrían que abandonar realmente, tal vez sólo el sistema de galerías y visualidad social. Es decir aquello en lo que ya no está el arte, sino más bien donde se le encubre y enmascara.

Este fue, sin duda, el sentido del gesto iconoclasta de Beuys (1921-1986) con su declaración de abandono del arte, con el que puso en operación el sueño vanguardista de la disolución del arte en la vida. Quizás haya que poder fracasar como artista para avanzar como hombre. Quizás deban descansar incluso los mismos poderes creadores de obras como terrenos ya demasiado explotados durante largo tiempo. Los desmontajes de la felicidad creativa muestran al arte la dirección para hacerse a un lado.

33 SLOTERDIJK, Peter, "El arte se repliega en sí mismo", Documenta XI. Kassel, En Revista Observaciones Filosóficas, Sección 2007. http://www.observacionesfilosoficas.net/elarteserepliega.html

${ }_{34}$ SLOTERDIJK, Peter, "El arte se repliega en sí mismo", Documenta XI. Kassel, En Revista Observaciones Filosóficas, $\quad$ Sección 2007. http://www.observacionesfilosoficas.net/elarteserepliega.html 
A Beuys el utopista, el pintor, el escultor, el diseñador gráfico, el performer, el teórico del arte, el político, el poeta, el dandy, el hombre de las cavernas, el profesor, el líder carismático, el chamán, el padre de familia, el héroe de guerra incombustible ${ }^{35}$, condecorado dos veces con la Cruz de Hierro, el que se reconvirtió en político pacifista y militante del partido verde, a él, no le interesaba exponer. Para Beuys exhibir fue siempre sólo una excusa para hablar de la utopía del Arte ante audiencias numerosas. Beuys fue un ácido crítico el sistema del Arte y se resistía a que su obra quedara confinada a galerías, museos y páginas culturales de la prensa del espectáculo.

Pese a la apuesta absoluta de Beuys por la utopía del continuo arte-vida, éste no es un tiempo del cual esperar mucho. "Pronto saldremos también de esta sala señala Sloterdijk en la introducción a una Exposición particular en Kassel-; y ninguna distancia habla ebria de una futura gran felicidad. Pero lo visto es lo visto. ¿Qué es visibilidad? Quizás la cotidianeidad de la revelación. ¿Qué es entonces revelación? Que algo nos ilumine con su visibilidad. Cuando estamos al aire libre. Cuando estamos tan afuera que el mundo se muestra"36.

\section{5.- EL ARTE DE LA INSTALACIÓN}

\section{1.- El Conceptualismo ruso, viviendas comunitarias y arte de la documentación en llya Kabakov. ${ }^{37}$}

Las raíces de la instalación en occidente descansa en los Happenings y en las acciones de Arte; la instalación es producto de lo que queda de algunos eventos congelados en el tiempo, como sucede en las instalaciones de Beuys, Kounellis y Merz. El origen de las instalaciones de Europa oriental reside en la pintura. La instalación occidental se orienta hacia el objeto, hacia la apariencia de los diferentes objetos después de la acción. La instalación en Europa oriental se dirige hacia el espacio, hacia la atmósfera de una situación particular. Tal es el caso del del maestro ucraniano Ilya Kabakov. ${ }^{38}$

$35 \quad$ Beuys sobrevivió envuelto en fieltro y grasa a las quemaduras tras un accidente del avión militar que pilotaba sobre Crimea.

36 SLOTERDIJK, Peter, "El arte se repliega en sí mismo", Documenta XI. Kassel, En Revista Observaciones $\quad$ Filosóficas, Sección 2007. http://www.observacionesfilosoficas.net/elarteserepliega.html

37 VÁSQUEZ ROCCA, Adolfo, "Ilya Kabakov; el Conceptualismo Ruso, viviendas comunitarias y el arte de la documentación", Homines, Málaga, 2008, http://www.homines.com/arte_xx/ilya_kabakov_arte_instalacion/

VÁSQUEZ ROCCA, Adolfo, "llya Kabakov; El arte de la instalación y el palacio de los proyectos". En Revista DU\&P Revista de Diseño Urbano y Paisaje, Universidad Central de Chile, Facultad de Arquitectura, Urbanismo y Paisaje, FAUP, ISSN 0717- 9758, Volumen V, No 15, Diciembre 2008.

http://www.ucentral.cl/dup/pdf/15_vaz_rocca_analogica.pdf 
Las instalaciones de Kabakov son construcciones complejas, no exentas de sátira e ironía, en las que se atiborran objetos, imágenes y textos recreando entornos deprimentes de viviendas comunitarias, clínicas mentales, aulas escolares y oscuros lugares de trabajo.

En las fotografías se aprecia cada uno de los objetos clasificados (un pequeño cristal roto, una madera diminuta, un fragmento de una cáscara de huevo, envases de leche de magnesia, cuentas de luz, cartas, botones, telegramas etc.). Una feroz inmersión en los universos mentales sofocantes, como una pared que de tanto cobijarnos comienza a estrecharse y termina por aprisionarnos, como la manía de acumular ya sea por miedo al futuro o simple avaricia. Recordemos que el mundo consiste en una multitud de proyectos, realizados algunos, a medio realizar otros, y algunos sin realizar. La acumulación no funcional -que aparece sublimada bajo la forma del coleccionismo- parece responder al deseo utópico y maníaco de evitar la dispersión y la fuga de las posesiones sean estas personas u objetos inanimados. Deseamos que el mundo comparezca todo y simultaneo sin puntos de fuga, en la claustrofobia del orden regulado según las más tiranas ideas que pueden apoderarse de nosotros.

Así la proliferación de las "instalaciones" parece una prueba más de la tendencia terapéutica del arte de exorcizar nuestros demonios haciéndoles frente por medio de montajes, sobre todo de objetos reales, de proyectos de obra, resoluciones y otros actos psicomágicos que también podemos calificar de hondo y sustantivo efecto espiritual. Las creaciones de artistas como Kabakov apuntan en este sentido a dotar al arte de los influjos terapéuticos a los que visionariamente Beuys $^{39}$ apuntara.

Entre sus últimas creaciones destaca la instalación "El hombre que voló al cosmos desde su departamento", presentado en en el Centro Georges Pompidou, París (1989).

Kabakov recupera el vigor del accionismo -esa tradición de artistas que supo sacar al Arte de la Galería- y mediante efectivos cruces entre palabra, imágenes y textos lograron conmovernos.

\section{2.- El Palacio de los Proyectos; Declaraciones mecanografiadas y delirio existencial.}

Sobrevalorado o no, trascendente o no, el artista ucraniano llya Kabakov se ha convertido en uno de los representantes más visibles del arte de la instalación en las dos últimas décadas. Su más reciente creación "El Palacio de los proyectos", como suele ocurrir con sus obras, no deja a nadie indiferente. Este trabajo recrea un imaginario lugar de madera, estructurado en diversas dependencias a las que el espectador accede como si se tratara de una tienda de muebles reciclados.

39 VÁSQUEZ ROCCA, Adolfo, "Joseph Beuys 'Cada hombre, un artista'; Los Documenta de Kassel o el Arte abandona la galería" (Reedición) En Revista Almiar, MARGEN CERO, MADRID, No 37 - diciembre de 2007 - Margen Cero (C) , Fundadora de la Asociación de Revistas Culturales de España, ISSN 1695-4807, http://www.margencero.com/articulos/new/joseph_beuys.html 
Cada estancia contiene elementos que varían de una a otra. Pero siempre puede encontrarse una silla y una mesa sobre la cual se halla un texto escrito (65 en total). Declaraciones mecanografiadas de seres anónimos de Moscú, Kiev y otras ciudades de la antigua Unión Soviética (hoy de países como Rusia o Ucrania).

En las instalaciones de llya Kabakov siempre se observa la presencia de la memoria, a veces con retazos autobiográficos, como el antiguo espacio de una casa, que después fue ruina, y luego dio paso sólo a la huella de la ruina. Esta huella es la memoria y la historia de otros.

Muchas veces la presentación de sus instalaciones, vivencias del pasado detenidas y extraídas, dejan una sensación de desolación, tristeza y necesidad de evasión.

Pese a todo siempre existe un lugar para la esperanza y ese lugar siempre está conectado con el pasado. Cada tiempo, cada espacio, cada territorio tienen imágenes simbólicas, que representan un cierto anclaje a determinadas ciudades y casas.

El arte contemporáneo se nos presenta de dos formas: una de ellas es la que muestran los museos y exposiciones, en las que el visitante está formado y sabe lo que está viendo o lo que espera ver. La otra es la de mostrarse a sí mismo como proyectos públicos, directamente dirigidos al espectador en general. No se trata de "teatro sólo para dramaturgos" sino para un público diverso y variado en cuanto a la profundidad de su conocimiento del arte. De esta forma, las reacciones frente a la obra de Kabakov pueden ser de sorpresa o desconcierto, pero jamas de indiferencia. La precariedad de sus obras puede ofrecernos las formas de un lirismo superior y convertirse en una nueva épica de la resistencia, llegando a ser un duro emplazamiento ante un mundo obsceno, una dura forma de responder a la cuestión de para qué arte en tiempos de indigencia.

\section{3.- El hombre que salto al Cosmos; de la Guerra Fría al proyecto Esferas}

La instalación "El hombre que salto al Cosmos" ${ }^{40}$ de llya Kabakov muestra una fantástica incursión en el universo de los últimos años del régimen comunista a través de la historia de un hombre que trata de escapar de su vida, e idea la manera de hacerlo, autopropulsándose y partiendo hacia el espacio. En su cuarto quedan sus zapatos y un agujero en el techo, prueba de que logró salir. Se dice que nunca más se ha sabido de él, con lo que su operación parece que resultó un éxito.

La imagen comporta una imagen evocativa que remite a hitos de la guerra fría, aquella que se libro entre las dos superpotencias en ámbitos tan disimiles como la

$40 \quad$ Catalogo de la Exposición "Cosmos", I. Kabakov: El hombre que voló al espacio desde su apartamento. (1981-1988). 
carrera espacial, los juegos olímpicos y los campeonatos mundiales de ajedrez; distintos frentes para un objetivo común, afirmar la hegemonía intelectual y tecnológica de uno de los bloques. Entre estos hitos, uno que significo un duro revés para el imperio americano sería la puesta en órbita del cosmonauta soviético Yuri Gagarin el 12 de Abril de $1961^{41}$, literalmente un hombre que salto al Cosmos. Y si se acentúa el aspecto de la explosión que debió tener lugar para expulsar al hombre al Cosmos -a enfrentar el frío inconmensurable del afuera [la helada cósmica a la que refiere Sloterdijk en su Proyecto Esferas]- ${ }^{42}$ asoma el devastador escenario del accidente de Chernobil $^{43}$, que forzó al gobierno de la Unión Soviética a la evacuación de unas 135.000 personas y provocó una alarma internacional al detectarse radiactividad en diversos países de Europa septentrional y central. Una nube radiactiva recorría Europa, diseminando muerte y mutaciones genéticas desconocidas, develando la vulnerabilidad de la tecnología nuclear soviética, inaugurando una nueva era en las preocupaciones ambientales que han movilizado no sólo a activistas en una égida ambientalista sino a nuevos artistas conceptuales convertidos en verdaderos profetas de la devastación.

\section{6.- ARTE PROCESUAL Y ARTE EFÍMERO}

41 En realidad, los pioneros de la Carrera Espacial fueron los alemanes. Allá por los años 40, la Alemania nazi desarrolló el primer cohete de la historia -el V2-. Fue un invento que desató miles de ambiciones. Luego vino el fin de la II Guerra Mundial y los secretos del Tercer Reich pasaron a manos de Estados Unidos y la Unión Soviética, los grandes protagonistas de la Guerra Fría. En el ambiente paranoico que se vivía entonces, no pocos creían que quien conquistara el espacio dominaría también la Tierra. Cuando Moscú lanzó el Sputnik 1 el 4 de octubre de 1957 puso en jaque el sueño estadounidense, no tanto desde el punto de vista tecnológico -el Sputnik 1 era un sencillo satélite de telecomunicaciones-, sino porque los soviéticos ganaron con ello la posibilidad de jactarse de haber sido los primeros. En 1962, el ahora mítico Yuri Gagarin fue el primer hombre que orbitó la Tierra. Un año más tarde, en medio de una masiva campaña publicitaria, Moscú volvía a levantar la bandera de la superioridad soviética al anunciar que Valentina Tereshkova se había convertido en la primera mujer en el espacio. Y en 1968, el cosmonauta soviético, Alexei Leonov, realizó la primera caminata espacial. Hasta que en 1969 por fin Estados Unidos pudo ser el primero. La promesa de Kennedy se cumplió el 20 de julio, cuando él ya había sido asesinado y Richard Nixon era quien gobernaba la Casa Blanca. Ese día, tras orbitar diez veces alrededor de la Luna, el astronauta Neil Amstrong posó el módulo Eagle y fue el primer hombre en dar unos pasos sobre la superficie lunar.

El mundo, sorprendido, vio el alunizaje por televisión. Pero habían sido tantos los fracasos estadounidenses frente a los soviéticos que incluso así muchos no lo creyeron. Nacieron así las múltiples teorías conspirativas que apuntaban a que la llegada a la Luna había sido un montaje, algunas de las cuales aún tienen defensores.

${ }_{42}$ VÁSQUEZ ROCCA, Adolfo, "Peter Sloterdijk; Esferas, helada cósmica y políticas de climatización", En EIKASIA. Revista de Filosofía, OVIEDO, ESPAÑA. ISSN 1885-5679, año I número 5- julio 2006, http://www.revistadefilosofia.com/SLOTERDIJK.pdf

$43 \quad$ La cantidad de material radiactivo liberado en la "Chornobil's'ka katastrofa", que se estimó fue unas 500 veces mayor que la liberada por la bomba atómica arrojada en Hiroshima en 1945, causó directamente la muerte de 31 personas, forzó al gobierno de la Unión Soviética a la evacuación de unas 135.000 personas y provocó una alarma internacional al detectarse radiactividad en diversos países de Europa septentrional y central. 
Por otra parte el término Process art da cuenta del trabajo de aquellos artistas para quienes la obra de arte no es tanto resultado de una organización formal de los materiales como presentación directa de los mismos, a fin de celebrar sus cualidades de tensión, despliegue y energía. El Process art -arte procesual- o arte en proceso, es así una actitud y un punto de vista creativo sobre el mundo donde el producto final del arte, el objeto de arte, no es el centro de atención principal. El "proceso" está ocupado con el hacer y el suceder simbólico, con el arte como ritual y performance.

El arte proceso no conserva objeto alguno, opera más bien como una interacción. La acción en tiempo real es capaz de romper la barrera que separa la expresión del creador de la vivencia del usuario. No se trata de un documento, sino de un acontecimiento que tiene lugar aquí y ahora. "El proceso sustituye en importancia al producto, igual que el sistema remplaza a la estructura". ${ }^{4}$

Las obras de arte de vida limitada -efímeras- o aquellas que se despliegan como procesos vivos en desarrollo (colaborativo), flujo y cambio son únicas en cuanto que resulta imposible repetirlas o reproducirlas de manera idéntica. Un carácter único que en el caso de algunas obras deriva de que fueron concebidas para tener la capacidad de responder al lugar concreto en el que se exponen, es decir, a aquello que la ciencia designa como condiciones 'iniciales'. El comportamiento de esta obra depende de los cambios de luz natural fuera del espacio expositivo. La arquitectura de la sala y la falta de luz natural en su interior obligan a instalar unos colectores de luz solar fuera de ella. No obstante, la forma en la que se muestra esa instalación revela la existencia de ese elemento y su papel de agente activo en el proceso.

Pero hay también obras que no son sensibles al entorno, mostrándose, en lugar de ello, totalmente aisladas del mismo.

Como muestra de la potencialidad del arte procesual pensemos, por ejemplo, en la ciudad como un organismo vivo constantemente reconfigurado tanto por el cambio acelerado como por la permanencia. Los procesos que tienen lugar en el interior de ese organismo avanzan a velocidades diferentes y en varios niveles de complejidad. Por vía de la integración del arte procesual en este dominio, los procesos cotidianos - por ejemplo, los flujos urbanos - pueden transferirse a movimiento dinámico y forma abstracta, convirtiéndose así en obras públicas y agentes activos dentro de los procesos más amplios de construcción de identidad y comunidad. ${ }^{45}$

\footnotetext{
44 ASCOTT, R. "Behaviourables and Futuribles", en Siles, K. and Selz, P. (ed.), Theories of Modern Art, University of California Press, Berkeley, 1996.

45 VÁSQUEZ ROCCA, Adolfo, "El vértigo de la Sobremodernidad; Turismo Etnográfico y Ciudades del Anonimato" Revista de Humanidades: TECNOLÓGICO DE MONTERREY No 22 (2007, primavera): Revista de Humanidades: Tecnológico de Monterrey, Instituto Tecnológico y de Estudios Superiores de Monterrey, pp. 211-223. http://www.redalyc.org/articulo.oa?id=38402208
} 


\section{1.- El Arte Efímero}

Es frecuente considerar obras de arte aquellos objetos realizados sobre una materia que permite ser conservada, coleccionada y museada. ${ }^{46}$ Pero arte no es sólo es una realidad objetiva, un artefacto configurado en una materia con formas y colores conservable, sino que es fundamental un proceso configurante de una realidad que se consume en experiencias comunicativas, casi siempre de valor simbólico, que terminan cuando el objeto se consume y agota, porque es de carácter efímero. ${ }^{47}$ Lo que queda es una imagen, un resto que puede ser museable, pero precisamente lo que no es museable son las experiencias, las funciones simbólicas o significativas producidas por los artefactos. Arte no sólo es lo coleccionable y museable, lo perenne, sino también lo no coleccionable y museable, lo efímero. En principio todo arte es efímero y pertenece a los ritos festivos, a los espacios donde se consumen los productos estéticos, a los elementos plásticos en los que el cuerpo humano sirve de soporte: vestidos, peinados, perfumes, maquillaje y comidas; a los elementos que sirven de nuevos medios técnicos que configuran la fiesta. Todo ello es fugaz, momentáneo, efímero, y no coleccionable, pero no por ello menos artístico que los artefactos museados.

\section{7.- LA IDEA COMO ARTE O EL ARTE DEL CONCEPTO}

Los artistas conceptuales han estado especialmente interesados en explorar una nueva zona de la especulación estética que parecía representar una dramática ruptura respecto a las habituales actividades de la producción contemplación y apreciación artísticas ${ }^{48}$. Abogaban por un decidido rechazo de los aspectos mercantiles del consumo de $a^{4 t e^{49}}$ y al mismo tiempo, muchos de ellos intentaban imbricar su actividad artística en un contexto más amplio de preocupaciones sociales, ecológicas e intelectuales, por oposición a la producción de objetos diseñados según criterios utilitaristas y funcionales al establishment cultural.

El arte conceptual es, pues, un arte crítico y corrosivo, pone énfasis en lo mental, en la ideación de las obras, relegando en importancia su realización material o sensible. Junto a este reduccionismo de lo manual, existe en las obras de arte

\footnotetext{
$46 \quad$ VÁSQUEZ ROCCA, Adolfo, "Estética de la virtualidad y deconstrucción del museo como proyecto ilustrado", En NÓMADAS, Revista Crítica de Ciencias Sociales y Jurídicas - Universidad $\begin{array}{llllll}\text { Complutense de } \quad N^{0} & \text { Madrid, } & 20 & \text { (2008.4), }\end{array}$ http://pendientedemigracion.ucm.es/info/nomadas/20/avrocca2.pdf

${ }_{47}$ FERNANDEZ ARENAS, José, (Coord.) Arte efímero y espacio estético, Editorial Anthropos, Barcelona, 1988, p. 9

BATTCOCK, Gregory, La idea como arte; documentos sobre el arte conceptual, Editorial Gustavo Gili, S.A., Barcelona, 1987, p. 9.

$49 \quad$ VASQUEZ ROCCA, Adolfo, "Baudrillard; cultura, narcisismo y régimen de mortandad en el sistema de los objetos" , en Revista Almiar, Margen Cero (Madrid; España) / № 31 / diciembre 2006 - enero 2007, http://www.margencero.com/articulos/articulos3/baudrillard.htm
} 
conceptual una hipervaloración del trabajo de arte, como una actividad reflexiva, tanto mental como experiencial. Puede decirse que el arte conceptual no se ha preocupado tanto del cómo cuanto del qué del arte.

En la obra de arte hay un 'qué', un sentido que pude ser interrogado. La obra de arte no sólo se da a ver, sino se da ha entender, se ofrece como asunto del pensamiento y esto, en la medida, en que se sustrae al régimen de la visibilidad.

De este modo las artes plásticas, mediante el arte del concepto dan un giro importante abandonando las poéticas de índole romántico-idealistas. A partir de este momento inciden sobretodo: la tendencia sintáctico-formal por una parte, la semántica-pragmática por otra, donde se presta menos atención a la sintáctica de las formas. Ambas alternativas sobrepasan las fronteras institucionalizadas de los géneros artísticos heredados de la tradición, y en una tercera tendencia se cuestiona el estatuto existencial de la obra como objeto.

Es así como el arte 'conceptual' enfatiza la eliminación del objeto artístico en sus modalidades tradicionales. De lo que se trata, por encima de un antiobjetualismo a ultranza e indiscriminado, es, como he señalado, de desplazar el énfasis sobre el objeto ('materialidad' de la obra) a favor de la concepción y del proyecto, de la conducta perceptiva, imaginativa o creativa del receptor. Incluso en los casos más extremos no puede darse una desmaterialización completa, pues las palabras escritas o en su oralidad son también "objetos" -y no primariamente culturalessino perceptivos a los que se les atribuye una significación. Es así como en la dimensión perceptiva de los signos podemos constatar que las relaciones, fórmulas y problemas introducidos por los matemáticos y lógicos crean también una actitud estética. Toda imagen puede ser reducida a una fórmula, signos, relaciones, vectores, etc. Existe una iconografía de la lógica y de la física, trazos matéricos, un dibujo del pensamiento, genéticamente contenido en sus signos.

El Arte conceptual también ha influido profundamente la evolución de la música contemporánea, teniendo en John Cage su principal representante. Es con John Cage que parece borrarse toda frontera entre el arte gráfico y las partituras. Cage interpreta dibujos y gráficos de manera musical y señala que ciertas partituras le permiten reconocer el decrecimiento de formas concretas y aisladas. Los escritos y partituras de John Cage han concitado el interés y generado discusiones entre los artistas conceptuales, quienes han tematizado ciertos aspectos de la creación conceptual en los terrenos del sonido, la composición y la interpretación musical.

En la música, decía Hegel, la oposición entre la obra y el espectador se minimiza y "no alcanza, como en las artes plásticas, la fijeza de un espectáculo permanente, exterior, que permite contemplar los objetos por sí mismos". 50 Es precisamente esa exterioridad, esa distancia, la que aspira a reconquistar la nueva música.

La música contemporánea, por el contrario, no querrá expresarse más que a sí misma; nacida en la misma cuna del positivismo lógico (tanto Hauer como

50 HEGEL, G. W. F., Estética, traducción de S. Jankélevich, Aubier, Paris, 1954, tomo III, primera parte, p. 307 
Schönberg eran vienes), responde a "la tendencia al juego numérico de la inteligencia vienesa, tan típico como el juego de ajedrez en los cafés". ${ }^{51}$ Es una música constructiva aunque no sea estrictamente combinatoria.

Tal el es caso de las composiciones de Arnold Schoenberg, las que las que subvierten las normas y tradiciones hasta entonces aplicadas a las estructuras musicales, para desarrollar lo que hoy conocemos como serialismo, donde todas las notas tienen el mismo valor y la lógica de la armonía es reemplazada por la lógica de la progresión de los tonos. ${ }^{52}$

\section{8.- POÉTICA E IMAGINARIO}

Ahora bien, si en el arte tradicional predominaba el objeto sobre la teoría, en el modelo sintáctico-semántico, desde la abstracción, se da un equilibrio hasta pasar a situaciones límite donde la teoría es más importante que el objeto (arte conceptual). Tan necesario como percibir la obra concreta es actualizar los conceptos teóricos anteriores a la misma, sus presupuestos productivos y receptivos.

Por ello no basta -desde que el arte conceptual ha hecho su irrupción y ha establecido sus demandas- con la mera intuición, con el mero oficio, hay también, o debe haber, algo programático, un imaginario, un ideario que el artista sigue y que sabe que sigue, esto es, una poética.

Este programa o imaginario siempre es previo a la concreción de la obra, sólo que no esta explicito para el propio autor. Sólo cuando su obra se ofrece -como textoa la lectura de las miradas que intentan desentrañar su sentido, posiblemente se sentirá interpelado a poner de manifiesto su imaginario, las preocupaciones y temáticas que informan su obra y le dan un sentido unitario. Sólo cuando existe esto podemos hablar de un autor, esto es, de alguien que tiene una obra, que tiene algo que decir y ha encontrado los medios expresivos para ello.

Es así como, por ejemplo, la obra y el programa de Duchamp nos muestra, tanto en una vertiente plástica como conceptual, las infinitas posibilidades de "lectura de lo real". En Duchamp encontramos el centro de gravedad de una concepción de las operaciones mentales y artísticas abierta a una lectura de lo real como diverso y plural, a una consideración flexible y distendida de la normatividad del mundo.

Nos encontramos así ante una operación de desmantelamiento epistemológico. El dispositivo opera sobre el pretendido rigor y objetividad de las ciencias duras. Sin duda una audaz maniobra subversiva, tan propia de las vanguardias de los años '20, las que superan con mucho -en su carácter corrosivo- a sus pálidos remedos

51 ADORNO, T. W., Filosofía de la música moderna, traducción de G. Manzoni, Turín, p. 67.

52 VÁSQUEZ ROCCA, Adolfo, "Música y Filosofía: registros polifónicos de John Cage a Peter Sloterdijk", en Revista Encuentros Multidisciplinares, Fundación General de la Universidad Autónoma de Madrid, Vol. 8, No 24, 2006, pp. 61-69. Reeditado en Cuenta y Razón del Pensamiento Actual, Fundación de Estudios Sociológicos de Madrid (Fundes), 2007, Fundada por Julían Marías, de periodicidad trimestral, www.cuentayrazon.org/revista/pdf/144/Num144_006.pdf . 
posmodernos.

La tras-vanguardia ya no es básicamente ruptura. Es academia y museo, se ha convertido en nuestra "tradición": en la tradición artística de la contemporaneidad. Desde los medios de comunicación de masas y las instituciones de la cultura, públicas o privadas, el horizonte estético de la vanguardia se transmite ya como clasicismo de la contemporaneidad ${ }^{53}$.

\section{9.- NUEVOS MEDIOS E HIBRIDACIÓN DE GÉNEROS}

El arte conceptual va a suponer también la introducción de nuevos enfoques y temas que harán de la narración, la apariencia, el texto, la autobiografía, la política feminista, la fragmentación y las ideas los principales actores de sus obras.

En los últimos años el arte contemporáneo ha sufrido cambios que afectan decisivamente al propio concepto de arte, como el surgimiento de prácticas artísticas (performance, happening, instalación) nuevas y otras (como la música, la danza o la escultura) que han modificado decisivamente su concepto, sus métodos y fines. Nuevos medios expresivos como el vídeo arte, el cine experimental o las nuevas relaciones entre la danza, el teatro y el vídeo, se constituyen en territorios de exploración y renovación plástica.

La influencia de los nuevos medios, el vídeo, la fotografía y la informática, la aparición de nuevas técnicas expositivas y museísticas, junto con la creciente interferencia de unas prácticas artísticas con otras han producido fenómenos de hibridación de géneros o de contaminación e interferencia de procedimientos y de lenguajes, que nos obligan en cierto modo a intentar clarificar los nuevos conceptos, con los que podemos pensar el arte contemporáneo y sus problemas. Estos nuevos conceptos del arte contemporáneo no sólo son pertinentes para pensar en aquello en lo que el arte contemporáneo nos quiere hacer pensar: las nuevas identidades sexuales, la espectacularización de lo social o nuestra relación con la violencia y con la muerte. Por eso he querido centrar este escrito introductorio específicamente en una discusión de los conceptos fundamentales que parecen regir el nuevo sistema de las artes.

\section{0. - LA OPERACIÓN DEL ARTE OBJETUAL}

La operación del arte objetual no consiste en una simple inserción de fragmentos u objetos de la realidad en la artificialidad del cuadro, de la escultura o del relieve sino en la instauración de un género nuevo. La reflexión entre los dos niveles icónicos habituales se desplaza hacia las propias relaciones asociativas de los objetos entre sí y respecto a su contexto interno y externo. No interesa para nada el objeto elegido aislado, encerrado en sí mismo, a no ser en sus transformaciones

53 JIMENEZ, José, La vida como azar; complejidad de lo moderno, Ed. Mondadori, Madrid, 1989, p.139. 
irónicas, satíricas, críticas o puramente estéticas, en una operación bastante alejada de las normas del arte establecido.

Por supuesto no se trata de un arte confortable, tibio y fácil de digerir, y no podía serlo porque con él tiene lugar una transformación donde los mismos escombros se convierten en testimonio de un nuevo arte. Por eso la ironía, por eso el urinario de Duchamp ${ }^{54}$, como escombro cultural de objeto rechazado, tan indesmentible como cotidiano.

A pesar de su extremada diversidad -body art, performance art, narrative art- lo que une a estas diversas manifestaciones que he venido anunciando, y que se han dado en denominar "arte conceptual" ${ }^{55}$, es su énfasis casi unánime sobre el lenguaje o sobre sistemas lingüísticamente análogos y la convicción de que "el lenguaje y las ideas son la verdadera esencia del arte."56 Ideas dentro, en torno y acerca del arte, transmitidas a través de medios escritos, registros fotográficos, formatos audiovisuales y documentos en general, es lo que constituye al arte del concepto. Este es un arte que existe, sin importar la forma que adopte; su existencia más plena y más compleja tiene lugar en las mentes de los artistas y de su audiencia. Es un arte que exige del espectador un nuevo tipo de atención y de participación, otorgándole a la experiencia estética un rol constructivo y crítico.

La hostilidad al objeto artístico tradicional, la extensión del campo del arte, la desestetización de lo estético, la nueva sensibilidad en sus diferentes modalidades, se insertan en la dialéctica entre los objetos y los sentidos subjetivos, en la producción no sólo de un objeto para el sujeto sino también de un sujeto para el objeto.

\section{1.- LA FUNCIÓN IRÓNICA DEL OBJETO}

A partir del momento en que son productos fabricados, artefactos, signos, mercancías, las cosas ejercen una función artificial e irónica por su propia existencia. Ya no es el deseo, como hicieran los surrealistas, de exagerar la funcionalidad, de enfrentar a los objetos al absurdo de su función en una irrealidad poética: las cosas se encargan de iluminarse irónicamente a sí mismas, se despojan de su sentido sin esfuerzo, sin necesidad de subrayar el artificio o el sin sentido a partir de la propia necesidad de su propia representación, del encadenamiento visible, demasiado visible, de su superficialidad, que crea en sí

54 VASQUEZ ROCCA, Adolfo, "La ficción como conocimiento, subjetividad y texto; de Duchamp a Feyerabend", En Psikeba -Revista de Psicoanálisis y Estudios Culturales- Buenos Aires, N $N^{0} 1$ - 2006 y Revista Observaciones Filosóficas, Sección Estética, 2007, http://www.observacionesfilosoficas.net/laficcioncomoconocimiento.html

55 Desde 1960, el arte "objetual", paralelamente a las diversas recuperaciones y a la vigencia de diferentes neodadaísmos, desbordará los límites del objeto para extenderse a los acontecimientos (happenings) y ambientes hasta llegar a los bordes mismos del arte conceptual.

56 STANGOS, Nikos (Compilador), Conceptos de Arte Moderno, Alianza Editorial, Madrid, 1997, p. 211. 
misma un efecto de parodia, o como en la patafísica ${ }^{57}$-el arte de soluciones imaginarias-, emparentada con la psico-magia ${ }^{58}$ donde el trauma y la neurosis son tratadas mediante operaciones simbólicas sobre el mundo. Todas las cosas, privadas de su secreto y de su ilusión, están condenadas a la ex-istencia publicitaria a su hacerse-ver. El mundo moderno es publicitario por esencia. ${ }^{59}$ Tanto así que se podría decir que ha sido inventado nada más que para hacer publicidad en otro mundo. No hace falta creer que la publicidad haya venido después de la mercancía: hay, en el corazón de la mercancía (y por extensión en el corazón de todo nuestro universo de signos) un genio maligno publicitario, un embustero que ha integrado la bufonería de la mercancía y su puesta en escena. ${ }^{60}$ Un escenógrafo genial ha dirigido al mundo hacia una fantasmagoría de la que todos somos por fin víctimas fascinadas.

Todas las cosas quieren hoy manifestarse. Los objetos técnicos, industriales, mediáticos, todos los artefactos quieren significar, ser vistos, ser leídos, ser registrados, ser fotografiados.

El sujeto ya no es más el operador de la ironía del mundo. Ya no es el sujeto quien se representa al mundo, es el objeto el que refracta al sujeto y que sutilmente, a través de nuestras tecnologías, le impone su presencia y su forma aleatoria.

\section{2.- ARTE POS-CONCEPTUAL}

Finalmente cabe una mención del incipiente fenómeno denominado por un sector de la crítica como arte posconceptual. Frente al arte conceptual donde la obra tiene un discurso que la constituye semánticamente, esto es, una descripción lingüística correlativa que la informa, existe el arte posconceptual, donde la obra tiende a la interacción directa, a una comunicación no verbal. Aquí la experiencia visual es presentada como una clase de conocimiento irreductible. Un arte que ofrece una particular resistencia a la domesticación. En un universo dominado por las metáforas, los mensajes y demás constructos discursivos puerilmente pretenciosos, vuelve a cautivar la intencionalidad estética contraria, la de bloquear el puente entre universos simbólicos diferentes.

En relación con esto, hoy reaparecen algunas cuestiones que se iniciaron con el Action Painting y que siempre han desafiado las convenciones del sistema de las Bellas Artes. La inmediatez del trazo y del gesto, de la mano y el cuerpo, de los medios así como del propio rito de pintar, incluida cierta violencia y primitivismo.

57 VASQUEZ ROCCA, Adolfo, "Alfred Jarry: patafísica, virtualidad y heterodoxia", Zona Moebius, United Nations Educational, Scientific and Cultural Organization, año 3 / noviembre diciembre

http://www.zonamoebius.com/lepoca_2003-2007/2005/001/avr_1004_jarry.htm

$58 \quad$ JODOROWSKI, Alejandro, Psicomagia, Ediciones Siruela, Madrid, 2004

59 DEBORD, G, La Sociedad del Espectáculo, Editorial Pre-Textos, Valencia, 2005.

60 BAUDRILLARD, Jean, El complot del arte. Ilusión y desilusión estéticas, Buenos AiresMadrid, Amorrortu, 2006. 
Consideraciones elementalísimas, como que la pintura es un líquido, y debe ofrecerse en su apariencia líquida, como en los goteados de Pollock. Hay, pues, un sentido de respecto a la naturaleza de las cosas que tiene un contenido ecológico de gran alcance. Frente a ello el arte conceptual -de tinte discursivo-, así como el pop, resultan altamente intencionados y manipulativos, desnaturalizando tanto la naturaleza polisémica de todo arte, como el rol constructivo del observador en la experiencia estética.

Es así como el arte 'conceptual' enfatiza la eliminación del objeto artístico en sus modalidades tradicionales. Pero salvo en casos extremos de la vertiente lingüística, existe menos una eliminación que un replanteamiento y crisis del objeto tradicional. ${ }^{61}$

\section{BIBLIOGRAFÍA}

ADORNO, Theodor W., Ästhetische Theorie, Frankfurt del Main, Suhrkamp, 1970

BAUDRILLARD, Jean, El complot del arte. Ilusión y desilusión estéticas, Buenos Aires-Madrid, Amorrortu, 2006.

BERNÁRDEZ SANCHÍS, Carmen, Joseph Beuys, Madrid, Ed. Nerea, 1998.

BEUYS, Joseph, Aprovechar a las ánimas. Fer profit a les animes, Catálogo de la Exposición, Sa Nostra. Caixia de Balears, y Diputación Provincial de Granada, 1992.

BEUYS, Joseph, Catálogo de la exposición, Szeemann, H. (com.), París, Musee National d'Art Moderne Centre Georges Pompidou, 1994.

BEUYS, Joseph, BODENMANN-RITTER Clara, Joseph Beuys: cada hombre, un artista: conversaciones en Documenta 5-1972, Editorial Visor, Madrid, 1995.

CIRLOT, Juan Eduardo, El mundo del objeto a la luz del surrealismo, Editorial Anthropos, Barcelona, 1986.

DEBORD, G, La Sociedad del Espectáculo, Editorial Pre-Textos, Valencia, 2005.

FEYERABEND, Paul, Tratado contra el método; Esquema de una teoría anarquista del conocimiento, Ed. Tecnos, Madrid, 2000

JIMENEZ, José, La vida como azar; complejidad de lo moderno, Ed. Mondadori, Madrid, 1989

HOFMANN, W. y THOMAS, K.: Beuys vor Beuys. Trabajos tempranos. Colección Van der Grinten, (Catálogo). Diputación de Zaragoza y Caja Madrid. Zaragoza, 1989.

61 MARCHÁN FIZ, Simón, Del Arte Objetual al Arte del Concepto; Epilogo sobre la sensibilidad 'postmoderna'; Ediciones Akal, Madrid, 1997, p. 251. 
IERARDO, Esteban "La liebre y el coyote; encuentros con lo animal y lo secreto en la obra de Joseph Beuys", en Temakel, 2005.

JODOROWSKI, Alejandro, Psicomagia, Ediciones Siruela, Madrid, 2004

GARDNER, James, ¿Cultura o Basura?, Acento Editorial, Madrid, 1996.

LAMARHE-VADEL, BERNARD, Joseph Beuys. Ed. Siruela. Madrid, 1994.

MACIUNAS: G. en AA.W : L' Espirit de Fluxus. Catálogo de la exposición en la Fundació Antoni Tapies. Barcelona, 1994

MARCHÁN FIZ, Simón, (1986) Del Arte Objetual al Arte del Concepto; Epilogo sobre la sensibilidad 'postmoderna' ; Ediciones Akal, Madrid, 1997.

MEYER, Ursula, Conceptual Art, Dutton, Nueva York, 1972.

STACHELHAUS, HEINER: Joseph Beuys. Ed. Parsifal. Barcelona, 1990.

STANGOS, Nikos (Compilador), Conceptos de Arte Moderno, Alianza Editorial, Madrid, 1997. 